\title{
The effect of progesterone, oestradiol and HCG on cell-mediated immunity in pregnant mice
}

\author{
Jan Carter \\ Department of Genetics, University of Edinburgh, West Mains Road, Edinburgh EH9 3JN, U.K.
}

\begin{abstract}
Summary. During pregnancy in mice, cell-mediated immunity as measured by a contact allergic reaction to picryl chloride was diminished $(P<0.001)$. Mice in which delay of implantation was maintained by progesterone, and mice with progesteroneand oestradiol-maintained pregnancies, also showed a reduction in the inflammatory response. The response of pseudopregnant mice did not differ from that of the nonpregnant controls. Young mice sensitized before complete immunological competence gave a $50 \%$ response. The response doubled in animals given a second sensitization. The extent of the response in females with delay of implantation varied inversely with the dose of progesterone. A range of oestrogen doses gave the same depression in the response when given to pseudopregnant animals. Administration of HCG to pseudopregnant mice also reduced the inflammatory response.
\end{abstract}

\section{Introduction}

It is generally accepted that, in mammals, cell-mediated immunity is depressed during pregnancy, although work by Currie (1970) has demonstrated that established immunity to paternal tissues is detectable during, but not affected by, pregnancy. Responses affected include the lymphocyte response to phytohaemagglutinin (Purtilo, Hallgren \& Yunis, 1972), reactions to microorganisms (Pickard, 1968; D'cruz, Balani \& Iyer, 1968), allografts (Heslop, Krohn \& Sparrow, 1954; Andreson $\&$ Monroe, 1962), and contact allergy (Fabris, 1973). The depression is thought to be due either to the formation of blocking antibodies (Ceppellini et al., 1971; Hellström \& Hellström, 1970), or to the particular hormonal balance during pregnancy (Billingham, 1964; Simmons \& Russell, 1966; Anderson, 1971). The two are not mutually exclusive, but the idea that the mechanism of nonrejection of the fetus is under the control of hormones has recently been given more attention.

In 1953, Medawar suggested that corticosteroids might be involved in the depression of the mother's immune response, and Diczfalusy (1964) showed that there was increased corticosteroid output during pregnancy. Kasakura (1973), however, has shown that cortisol is not the active component in the depression of the mixed leucocyte reaction by pregnancy plasma in man.

Oestrogens inhibit cutaneous delayed hypersensitivity reactions (Laurie, Harris, Abramson \& Allinson, 1949; Kappas, Jones \& Roitt, 1963), but there are conflicting reports about their use for inhibiting allograft rejection (Krohn, 1954; Medawar \& Sparrow, 1956; Simmons, Price \& Ozerkis, 1968; Waltman, Burde \& Berios, 1971).

Black, Simon, McNutt \& Casida (1953) demonstrated that pseudopregnant rabbits treated with progesterone, or with progesterone plus oestrogen, developed pyometra after injection of contaminated rabbit semen into the uterus, whereas controls did not. The results of Turcotte, Havies, Brodij, Meyer \& Schwartz (1968) have shown that progesterone can increase allograft survival time. The survival time of allografts placed in the uteri of pregnant rats, or non-pregnant rats treated with progesterone and oestrogen, has been increased by 33\% (Watnick \& Russo, 1968). Monroe (1971) induced sarcomas with Rous virus in normally resistant, progesterone-treated monkeys: HCG when given to female, but not male, monkeys had the same effect.

Contractor \& Davies (1973) observed immuno-suppression of lymphocyte transformation by HCG and human chorionic somatomammotrophin. They suggested that non-rejection of the fetus may be under the control of placental polypeptide hormones. 
Skin reactions, such as those evoked by oxazolone and picryl chloride, are regarded as examples of delayed-type hypersensitivity (cell-mediated immunity) (Asherson \& Zembala, 1970; Asherson $\&$ Ptak, 1970). Using such a reaction to picryl chloride, Fabris (1973) observed that mice sensitized before pregnancy and then tested during pregnancy showed a diminished inflammatory response. The present investigation used this technique to look at the effects of progesterone, oestradiol and HCG on cell-mediated immunity during pregnancy in mice.

\section{Materials and Methods}

Randomly bred Q-strain virgin females ranging in age from $4 \frac{1}{2}-10$ weeks were used. Contact allergy was induced by painting the shaved abdomen with $0.1 \mathrm{ml}$ of a $1 \%$ solution of picryl chloride $(2,4,6$ trinitrochlorobenzene: B.D.H. Chemicals Ltd) dissolved in absolute ethanol. The mice were paired 35 days later with vasectomized or intact males of the $Q$ strain; only mice that mated within 7 days of pairing were used. The day of finding the vaginal plug was taken to be Day 1 of pregnancy or pseudopregnancy.

Tests were conducted on (i) control mice which received a challenge 38 days after the initial sensitization; (ii) intact pregnant mice; (iii) 'delayed' pregnant mice which were pregnant mice ovariectomized on Day 3 to cause a delay of implantation which was maintained by administration of progesterone from Day 5. Oestrogen was given on Day 13 and only mice which had implantation sites 5 days later were considered; (iv) pseudopregnant mice; (v) 'hormonally' pregnant mice which were pregnant mice ovariectomized on Day 3 and treated with $1 \mathrm{mg}$ progesterone plus $0.025 \mathrm{ng}$ oestradiol/day from Day 5-a regimen intended to mimic hormonal conditions during pregnancy (Martin \& Finn, 1968). The numbers of mice in each group and the specific details of each experiment are described in the 'Results' section.

Stock solutions of progesterone (B.D.H.) and oestradiol-17ß (Koch-Light) in absolute ethanol were used to make up the necessary arachis oil solutions for injection; $0.1 \mathrm{ml}$ was given subcutaneously. HCG (Organon) was administered intraperitoneally in $0.1 \mathrm{ml}$ water.

On Day 10 the mice were challenged by placing one drop from a 26-gauge needle of a $1 \%$ solution of picryl chloride in arachis oil on either side of the lower lobe of the pinna. The resulting inflammatory response, manifested as erythema and swelling of the ear lobe, was measured 24, 48 and $72 \mathrm{hr}$ later with a micrometer. Two measurements were taken blind on each day. Control measurements were made for each mouse on the first 5 days of pregnancy. Differences in ear thickness, expressed in $10^{-3} \mathrm{~cm}$, were calculated by subtracting the average of the 10 initial measurements from the average of the 4 experimental measurements per mouse per day.

Tests of significance on the slope and elevation of regression lines were conducted according to the least squares regression method described by Snedecor \& Cochran (1967).

\section{Results}

In Exp. 1 (Text-fig. 1a) there was a clear depression in the allergic reaction to picryl chloride in 'intact' or 'hormonally' pregnant mice, and in animals kept in 'delay'. There were highly significant differences in elevation between the results for control and pregnant $(P<0.001)$, control and 'hormonally' pregnant $(P<0.001)$, and control and 'delayed' pregnant animals $(P<0.01)$; those for the control and pseudopregnant animals were not significantly different $(P>0 \cdot 2)$. The slopes of all the regression lines were not significantly different. Comparison of the pregnant mice with those in 'delay' showed no significant difference in slope or elevation $(P>0 \cdot 2)$, but there were differences in elevation between pregnant and pseudopregnant $(P<0 \cdot 01)$ and pregnant and 'hormonally' pregnant animals $(P<0 \cdot 05)$.

The differential between the groups was maintained in the experiment illustrated in Text-fig. 1(b), although the overall response was greater. Regression analysis of the elevation showed a significant difference $(P<0.05)$; the slopes were the same $(P>0 \cdot 2)$. The results of the experiment depicted in 


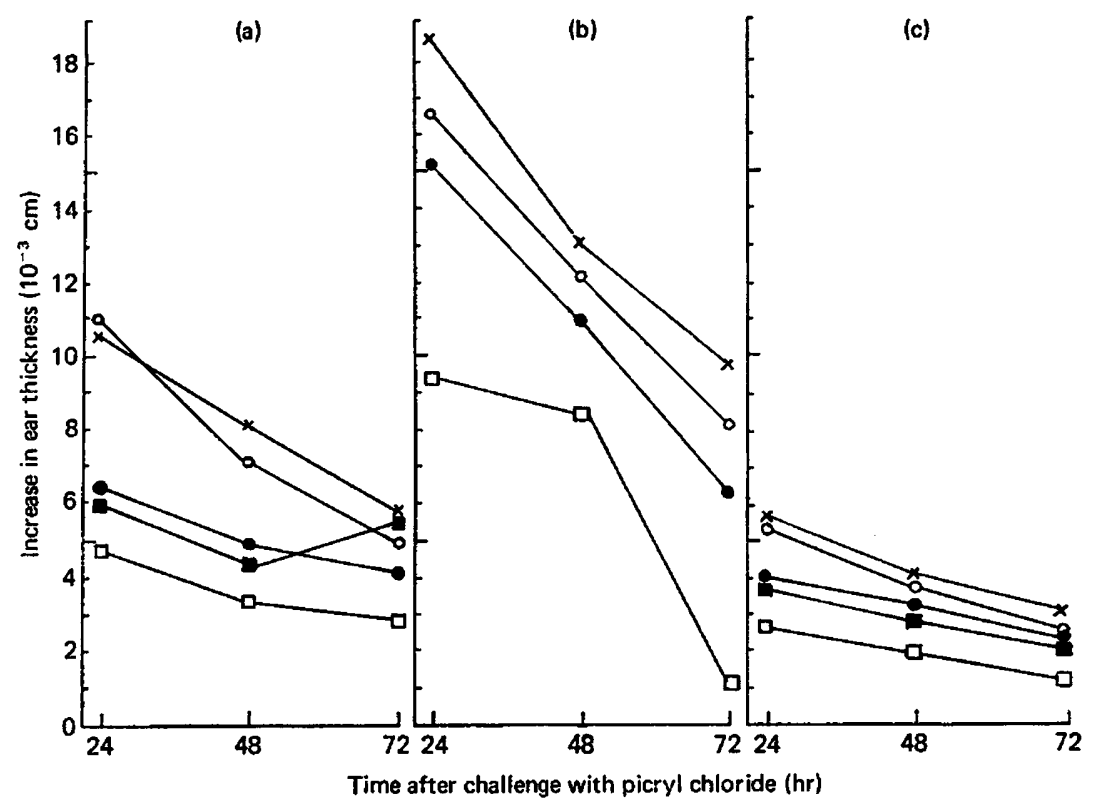

Text-fig. 1. Increase in the ear thickness of mice after challenge with 1 drop of a $1 \%$ solution of picryl chloride in arachis oil on Day 10 of pregnancy. (a) Response of animals sensitized at 6 weeks of age and challenged 35-42 days later, 7 mice/point; (b) response in animals sensitized at 6 weeks of age and resensitized on Day 3 of pregnancy before challenge on Day 10,8 mice/point; (c) response in animals sensitized at $4 \frac{1}{2}$ weeks of age, 6 mice/point. $\times$, Control mice; $\square$, 'hormonally' pregnant mice $(1 \mathrm{mg}$ progesterone $+0.025 \mathrm{ng}$ oestradiol each day from Day 5 of pregnancy); 0 , pseudopregnant mice; $\bullet$, pregnant mice; $\mathbf{m}$, animals in implantation delay (ovariectomy on Day 3 of pregnancy, $1 \mathrm{mg}$ progesterone each day from Day 5 and $0.025 \mathrm{ng}$ oestradiol from Day 13).

Text-fig. 1c showed that the overall level of the response was lowered; there was, however, a significant difference in the elevation $(P<0 \cdot 05)$, but not in slope $(P>0 \cdot 2)$.

Comparison of the effects of different doses of progesterone given to animals in 'delay' are shown in Table 1. Linear regression analysis showed that there was no significant difference in the slopes of the lines for each dose $(P>0 \cdot 2)$, but a highly significant difference in the elevation $(P<0 \cdot 001)$. In the same experiment, pseudopregnant mice were compared with pseudopregnant animals that received progesterone (Table 1b). There was a $65 \%$ depression in the response at 24 and $48 \mathrm{hr}$, and regression analysis showed that the slopes of the lines varied $(P<0 \cdot 01)$.

Table 1. The effect of progesterone on the increase in the mean ( \pm S.E.M.) ear thickness $\left(10^{-3} \mathrm{~cm}\right)$ of mice (7/group) after challenge with $1 \%$ picryl chloride $35-42$ days after sensitization

\begin{tabular}{lccc}
\hline & \multicolumn{3}{c}{ Time after challenge with picryl chloride (hr) } \\
\cline { 2 - 4 } Dose of progesterone (mg) & 24 & 48 & 72 \\
\hline (a) 'Delayed' pregnant mice & & & \\
0 (controls) & $8.3 \pm 0.3$ & $5.9 \pm 0.8$ & $5.3 \pm 1.4$ \\
0.05 & $5.1 \pm 0.8$ & $4.7 \pm 0.4$ & $3.9 \pm 1.1$ \\
0.5 & $3.4 \pm 0.7$ & $2.0 \pm 0.6$ & $2.4 \pm 0.9$ \\
5.0 & $4.2 \pm 0.4$ & $1.8 \pm 0.8$ & $1.9 \pm 0.7$ \\
10.0 & $1.0 \pm 0.4$ & $0.9 \pm 0.2$ & $0.5 \pm 0.4$ \\
(b) Pseudopregnant mice & & & \\
$\quad$ (controls) & $6.6 \pm 0.4$ & $5.1 \pm 0.5$ & $2.3 \pm 0.6$ \\
1.0 & $2.3 \pm 0.5$ & $1.6 \pm 0.4$ & $1.3 \pm 0.2$ \\
\hline
\end{tabular}




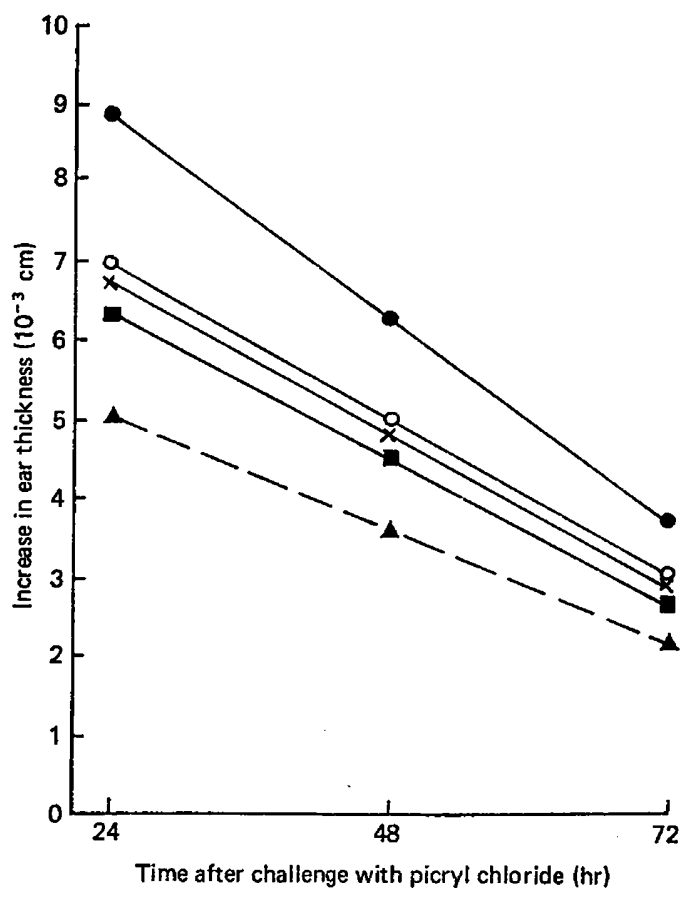

Text-fig. 2. The effect of oestradiol, with or without progesterone, on the increase in ear thickness in pseudopregnant mice, 7 mice/point. Hormone injections were given daily from Day 5 of pregnancy. The linear regression line formulae were: $\bullet$, pseudopregnant mice, $y=11.5+1.07 x ; \times, 0.0025 \mathrm{ng}$ oestradiol, $y=10.65+0.79 x ; 0,0.025 \mathrm{ng}$ oestradiol, $y=9.3+0.84 x ; \Delta, 0.025 \mathrm{ng}$ oestradiol $+0.05 \mathrm{mg}$ progesterone, $y=7 \cdot 7+0.59 x ; \square, 0.25 \mathrm{ng}$ oestradiol, $y=8 \cdot 1+0 \cdot 77 x$, where $y=$ increase in ear thickness $\left(10^{-3} \mathrm{~cm}\right)$ and $x=$ time in hours after challenge with picryl chloride.

The effect of oestradiol treatment of pseudopregnant mice is shown in Text-fig. 2. There was no difference in elevation between the three doses $(P>0 \cdot 2)$, but there was a significant difference from control $(P<0.001)$. The slopes of the lines did not differ. In the same experiment, two groups of mice received oestradiol and progesterone. The effect of the combination when $0.0025 \mathrm{ng}$ oestradiol was used was not significantly different from that when oestradiol was given alone $(P>0.2)$, but there was a significant difference when $0.025 \mathrm{ng}$ was used $(P<0.01)$. When 5 i.u. HCG were given, the response (mean ear thickness ( \pm S.E.M.) $10^{-3} \mathrm{~cm}, 7$ mice/group) was less than that in pseudopregnant mice at all times tested:

\begin{tabular}{lccc}
\hline & $24 \mathrm{hr}$ & $48 \mathrm{hr}$ & $72 \mathrm{hr}$ \\
\hline Pseudopregnant & $7.0 \pm 0.2$ & $6.8 \pm 0.5$ & $5.1 \pm 0.7$ \\
5.0 i.u. HCG & $5.0 \pm 0.6$ & $4.5 \pm 0.7$ & $3.6 \pm 0.8$ \\
\hline
\end{tabular}

There was no difference in the slope of these two groups $(P>0 \cdot 2)$, but the difference in elevation was highly significant $(P<0 \cdot 001)$.

\section{Discussion}

A depression of cell-mediated immunity has been shown in pregnant mice, as measured by an assay based on delayed-type sensitivity to picryl chloride. This result confirms the work of Fabris (1973) in which a maximum depression was shown $24 \mathrm{hr}$ after challenge on Day 10 of pregnancy. In the 
present study, this depression was mimicked in 'hormonally' pregnant mice and in mice in which implantation was delayed.

Pregnant mice receiving oestradiol and progesterone daily from Day 5, after ovariectomy on Day 3, showed a lower response than intact pregnant animals, suggesting that hormone levels in the treated mice are higher than those in normal pregnancy. Mice kept in delay of implantation showed a response which did not differ from that of pregnant animals. The oestradiol, therefore, either alone or in synergism with progesterone, must be responsible for the lowering of the response in the hormone-maintained pregnant mice.

Pseudopregnant mice did not differ from controls in their response, presumably because by Day 10 of pregnancy their hormone levels were almost back to non-pregnant levels. Administration of progesterone daily from Day 5 , however, reduced the response in pseudopregnant mice, eliminating the possibility that the blastocyst might be involved in the depression of the response.

When young mice ( $4 \frac{1}{2}$ weeks of age) were sensitized, the overall response was halved, but the same relationships between the groups was found (Text-fig. 1c). Full immunological competence is thought not to be achieved until approximately 6 weeks of age in mice.

The doubling of the overall response when mice were sensitized a second time 7 days before challenge indicates an additive effect of the second sensitization, with more sensitized lymphocytes being formed.

Progesterone is known to be an immunosuppressive agent (Monroe, 1971). A dose-response effect was shown in the present experiments; $0.05 \mathrm{mg} /$ day proved inadequate to maintain pregnancy, but nonetheless had an effect on the reduction of the response to picryl chloride, while $10.0 \mathrm{mg} /$ day abolished the response entirely.

There was no dose-response effect of oestradiol; $0.025 \mathrm{ng}$ is sufficient to induce and maintain pregnancy in mice (Martin \& Finn, 1968), and in these experiments this dose, $0.0025 \mathrm{ng}$ and $0.25 \mathrm{ng}$ all had the same effect. When a dose of $0.05 \mathrm{mg}$ progesterone was given with $0.025 \mathrm{ng}$ oestradiol, there was a further lowering of the response. As $0.05 \mathrm{mg}$ of progesterone alone failed to reduce the response much below control levels, it would appear that there is a synergistic effect of the two hormones. The response did not change significantly when the same dose of progesterone was given with $0.0025 \mathrm{ng}$ oestradiol.

Recent work by Hanson, Powell \& Steven (1971) and Niswender, Menon \& Jaffe (1972) has shown that if HCG is administered to women during the luteal phase of the menstrual cycle, there is an elevation in plasma progesterone levels and an extension of the life of the CL. The placental hormones have also been implicated in the mechanism for the non-rejection of the fetus by the mother (Contractor \& Davies, 1973; Borland, Loke \& Wilson, 1974), directly or by control of progesterone secretion. It was therefore of interest that $\mathrm{HCG}$ administered daily from Day 5 of pregnancy, in a dose adequate to stimulate ovulation in mice (Fowler \& Edwards, 1957), depressed the delayed-type hypersensitivity response in the present study.

Progesterone and oestrogen are important in the maintenance of pregnancy. It has been suggested that they may play a part in the control mechanism for the depression of cell-mediated immunity during pregnancy (Fabris, 1973; Kasakura, 1973). In the present study, physiological doses of progesterone and oestrogen depressed delayed-type sensitivity to the same degree as occurs in normal pregnancy.

I am grateful to the Ford Foundation for financial support, to Dr Anne McLaren for her continued interest and advice and to Mrs E. Chorley for skilled technical assistance.

\section{References}

ANDERSON, J.M. (1971) Transplantation-Nature's success. Lancet ii, 1077-1082.

ANDRESON, R.H. \& MONROE, C.W. (1962) Experimental study of the behavior of adult human skin homo- grafts during pregnancy. Am. J. Obstet. Gynecol. 84, $1096-1103$.

Asherson, G.L. \& PTAK, W. (1970) Contact and delayed hypersensitivity in the mouse. III. Depression of 
contact sensitivity by pre-treatment with antigen and the restoration of immune competence in tolerant mice by normal lymphoid and bone marrow cells. Immunology 18, 99-106.

Asherson, G.L. \& Zembala, M. (1970) Contact sensitivity in the mouse. IV. The role of lymphocytes and macrophages in passive transfer and the mechanism of their interaction. J. exp. Med. 132, 1-15.

Billingham, R.E. (1964) Transplantation immunity and the maternal-fetal relation. New Engl. J. Med. 270, 667-672.

Black, W.G., Simon, J., McNutt, S.H. \& Casida, L.E. (1953) Investigations on the physiological basis for the differential response of estrous and pseudopregnant rabbit uteri to induced infection. $A m$. $J$. vet. Res. 14, 318-323.

BORLAND, R., LOKE, Y.W. \& WILSON, D. (1974) Immunological privilege resulting from endocrine activity of trophoblast in vivo. In Immunobiology of the Trophoblast, pp. 157-169. Eds R. G. Edwards, C. S. Howe \& M. H. Johnson. Cambridge University Press.

Ceppellini, R., Bonnard, G.D., Coppo, F., Miggiano, V.X., Posisil, M., Curtoni, E.S. \& Pellegrino, M. (1971) Mixed leucocyte cultures. HL-A antigens. 1. Reactivity of young foetuses, newborns and mothers at delivery. Transplant. Proc. 3, 58-70.

Contractor, S.F. \& Davies, H. (1973) Effect of human chorionic somatomammotrophin and human chorionic gonadotrophin on phytohaemagglutinin-induced lymphocyte transformation. Nature, $\mathrm{New} \mathrm{Biol.}$ 243, 284-286.

Currie, G.A. (1970) Effect of interstrain pregnancy on the immune status of female mice sensitized to paternal antigens. J. Reprod. Fert. 23, 501-503.

D'CRUZ, I.A., BALANI, S.G. \& IYER, L.S. (1968) Infectious hepatitis and pregnancy. Obstet. Gynec., N.Y. 31, 449-455.

Diczfalusy, E. (1964) Endocrine functions of the human fetoplacental unit. Fedn Proc. Fedn Am. Socs exp. Biol. 23, 791-798.

FABRIS, N. (1973) Immunological reactivity during pregnancy in the mouse. Experientia 29, 610-612.

Fowler, R.E. \& EDwards, R.G. (1957) Induction of superovulation and pregnancy in mature mice by gonadotrophins. J. Endocr. 15, 374-384.

Hanson, F.W., Powell, J.E. \& Steven, V.C. (1971) The effects of HCG and human pituitary LH on steroid secretion and functional life of the human corpus Juteum. J. clin. Endocr. Metab. 32, 211-215.

Hellström, K.E. \& Hellström, I. (1970) Immunological enhancement as studied by cell culture techniques. A. Rev. Microbiol. 24, 373-398.

Heslop, R.W., Krohn, P.L. \& Sparrow, E.M. (1954) The effects of pregnancy on the survival of skin homografts in rabbits. $J$. Endocr. 10, 325-332.
KaPpaS, A., JoNes, H.E.H. \& RoIm, I.M. (1963) Effects of steroid sex hormones on immunological phenomena. Nature, Lond. 198, 902.

KASAKURA, S. (1973) Is cortisol responsible for inhibition of MLC reactions on pregnancy plasma? Nature, Lond. 246, 496-497.

KROHN, P.L. (1954) The effect of steroid hormones on the survival of skin homografts in the rabbit. J. Endocr. 11, 78-82.

Laurie, M.B., Harris, T.N., Abramson, S. \& AllinSON, J.M. (1949) Constitutional factors in resistance to infection. Am. Rev. Tuberc. pulm. Dis. 59, 186197.

Martin, L. \& FinN, C.A. (1968) Hormonal regulation of cell division in the epithelial and connective tissues of the mouse uterus. J. Endocr. 41, 363-371.

Mrdawar, P.B. (1953) Some immunological and endocrinological problems raised by the evolution of viviparity in vertebrates. Symp. Soc. exp. Biol. 7, 320-338.

Medawar, P.B. \& Sparrow, E.M. (1956) The effects of adrenocorticol hormones, adrenocorticotrophic hormone and pregnancy on skin transplantation immunity in mice. J. Endocr. 14, 240-256.

Monroe, J.S. (1971) Progesteroids as immunosuppressive agents. J. Reticuloendothelial Soc. 9, 361375.

NisWender, G.D., MenON, K.M.J. \& JAFFE, R.B. (1972) Regulation of the corpus luteum during the menstrual cycle and early pregnancy. Fert. Steril. 23, 432-442.

PICKARD, R.E. (1968) Varicella pneumonia in pregnancy. Am.J. Obstet. Gynec. 101, 504-508.

Purtilo, D.T., Hallgren, H.M. \& Yunis, E.J. (1972) Depressed maternal lymphocyte response to phytohaemagglutinin in human pregnancy. Lancet i, 769-771.

Simmons, R.L. \& Russell, P.S. (1966) The histocompatibility antigens of fertilized mouse eggs and trophoblast. Ann. N.Y. Acad. Sci. 129, 35-45.

Simmons, R.L., Price, A.L. \& Ozerkis, A.J. (1968) The immunologic problem of pregnancy. Am. J. Obstet. Gynec. 100, 908-911.

Snedecor, G.W. \& Cochran, W.G. (1967) Statistical Methods, 6th edn, pp. 432-436. Iowa State University Press.

Turcotte, J.G., Havies, R.F., Brody, G.L., Meyer, T.J. \& SCHWARTZ, S.A. (1968) Immunosuppression with medroxyprogesterone acetate. Transplantation, 6, 248-260.

WaltMan, S.R., Burde, R.M. \& Berios, J. (1971) Prevention of corneal homograft rejection by estrogens. Transplantation 11, 194-196.

WATNICK, A.S. \& Russo, R.A. (1968) Survival of skin homografts in uteri of pregnant and progesteroneoestrogen treated rats. Proc. Soc. exp. Biol. Med. $128,1-4$ 